\title{
Formation of a Civic Identity System in School Education and Popular Culture (Using the Example of the USA)
}

\author{
Yaroslav Levin ${ }^{1, *}$ Alexander Buranok ${ }^{1}$ \\ ${ }^{1}$ Samara State University of Social Sciences and Education, Samara, Russia \\ *Email: yaroslavlevin1992@mail.ru
}

\begin{abstract}
The article is devoted to such a complex issue as the development of ideas about civic identity. The topic of approaches to this ideological construction in the 20th century USA, primarily within the framework of school education, is considered. In addition, the review examines the reflection of the most important postulates of American identity in popular culture, which in the general context of the topic acts as an additional, and often even the primary source of forming ideas of the younger generation of Americans about their place in the country, the rights and duties of a citizen. The author proceeds from the fact that the study of the American experience will allow us to understand better the development of ideas about identity in the USA, as well as optimally perceive the best practices of the American education system and mass culture in these areas, at the same time, a critical analysis will allow us to see how negative features have formed in this system at the present stage. It has been proved that today, although the United States remains one of the countries with the highest level of civic consciousness in the field of education and upbringing, new paradigms are being formed that counter to all previous experience and blur the values and ideals that are familiar to many generations of Americans underlying the development of civic identity and patriotism.
\end{abstract}

Keywords: Civic identity, Patriotism, American education system, popular culture, USA.

\section{INTRODUCTION}

The problem of understanding one's place in the world, belonging to one's country and one's people, is one of the cornerstones in the process of forming nation-states. The United States faced it at the beginning of its historical development, still being a de facto colony of Great Britain. Already in the first decades of the existence of the British colonies on the American continent, they began to develop their folklore, traditions and customs, the self-perception of the colonies is still being formed as part of the "British world", but a particular feature, unique, radically different from other dependent territories of the British Empire. At the same time, the language of the colonists is also changing; slangs and dialects are gradually merging into a new linguistic structure based on classical English, becoming the basis for what is commonly called "American English" today, a unique accent of different parts of the future country is being developed, which clearly distinguishes Americans from the British [1].

These processes are unified and consolidated in the first American schools, which have become hotbeds of the development of American self-consciousness for several decades. All this is superimposed on the religious and ethical aspect, in which Puritan morality and the ethic system are moving away from the Anglican Church. Thus, by the beginning of the American Revolutionary War in 1775, the genesis of American civic identity was in the final stages. It is clear that the demands for political autonomy or complete independence under such conditions were a 
matter of time. All this was superimposed on the irreconcilable position of the British Crown, which did not want to recognise the "special position" of the colonies in the New World [2, pp. 19-43].

The result of all this was a long war for independence, which finally consolidated Americans' perception as a new nation.

A detailed analysis of these phenomena can be found in a remarkable internal study of the US Department of Education. Already in the introductory article, it is noted that historical and political changes in the status of the young American state directly affected the development of education as a whole and its formative role in the process of creating a unique, "proper American" civic identity [3, p. 3-19].

\section{THE 20TH CENTURY AND CHANGES IN EDUCATION AND UPBRINGING}

The further historical development of the educational functions of education in the USA was based on several basic ideological concepts, which in many respects are still decisive in the social and political life of this country. First, it is possible to single out the concept of "American exceptionalism", which presupposes the unique position of the United States in the community of other Western countries as a state, created on democratic principles from the first days and did not know tyranny. This was well aligned with the religious context of God's election, eventually transforming into the idea of a uniquely American mission - to be a model for other countries. In addition, American education up to the beginning of the 20th century was based on the concept of a "melting pot" in which American ones organically replaced all the national characteristics and traditions of many migrants. Finally, education in this country has always been characterised by pragmatism, focusing on educating a person capable of starting a business and being comprehensively independent. It is this idea that in the 20th century is transformed into the famous "American dream" - financial and political independence of citizens [4, p. 200-212].

Nevertheless, by the beginning of the 20th century, American education began to lag the growing desire in society for greater openness to the world. As you know, until the second half of the 19th century, the United States was a relatively closed country, closed on the development of its continent and little interested in European politics and international relations. Several researchers note that education in the United States sensitively followed the isolationist model, and knowledge about other countries in the course of general history and geography became increasingly fragmentary and reference. The two World Wars seriously changed the way of American life, as well as the geopolitical confrontation with the USSR that followed the Second World War. Significant changes have also taken place in the field of civic education [5, p. 36].

The US experience is reasonably considered highly successful and interesting with the structure and principles of organisation of this sphere. Moreover, the main goal of civic education in the USA is the ability to adapt adequately to numerous changes in the way of life. In a period of general instability in the world and transformation in politics and culture, this is a beneficial quality of personality, ensuring its organic adaptation and transition to a new, more appropriate to the particular time condition.

Actions to include young Americans in the civil identity of the country based on common ideas are beginning to unfold widely at school, within the framework of various programs of civic education of schoolchildren. First, this is the study of the basics of civics; also critical is the preparation for national holidays, the survey of patriotic songs, excursions to historical sites of federal and local significance. In addition, in many public and private schools, the school day begins with a ceremony of raising and swearing allegiance to the American flag, which is installed in every classroom, etc. Textbooks, educational films, various celebrations, and holidays steadily form the idea among schoolchildren that "the USA is the best country in the world," that "You are citizens of the freest country," etc. Bright posters with slogans such as "Proud to be an American" are often placed in classrooms. Proud to be American) [6, pp. 87-88]. Flag Day is a separate and significant public holiday with its developed mythology. It is accompanied by solemn speeches, the performance of patriotic songs, games on the knowledge of the geography of the United States and the history of the flag. The star-spangled banner plays a vital role in socialisation, as many schools, as noted above, begin the day by raising the flag, as well as singing the anthem. It acts as a mandatory attribute at official events and many non-governmental events, such as sports competitions. Z.A. Malkova believes that the proof of state control over civil education is most clearly the law "On National Goals of Education" 
adopted in 1994. This law clearly states that schools should "train responsible citizens" [7, p. 258].

Role-playing games, debates, and speaker competitions are widely used to form young Americans' political and civic culture and identity. For example, we can give the game "Strike", developed in one of Portland (Oregon) schools. As part of the game, students played industrialists, workers, trade union leaders, government officials, civil activists according to the parameters of various life situations set by teachers. Currently, such educational role-playing games are trendy in schools in the USA and throughout the Western world. Another game of this type that has gained popularity among students and the respect of teachers and scientists is "Elections". During the course, teachers prepare a scenario for a political campaign, various candidates are nominated for a particular post, election programs, advertising and campaigning are being prepared, and voting is being held. But for the education of civic identity and general political culture among young people, one school is not enough. Therefore, in the United States, there is a program "Close Up". It includes introducing teenagers to various socio-political shows, seminars, sightseeing tours, in which teenagers have explained the principles and mechanisms of the activities of the main state structures (Congress, the Supreme Court, the White House, etc.) in a language they understand. Also, for the work of this program, a special yearbook of internal and external events is issued, designed to introduce high school students to social studies classes. Thus, even devoutly apolitical young people have at least basic knowledge about their state and world, as well as intra-American events. Another essential component of civic education and identity in the USA is student self-government, a relatively developed system of posts with its functionality. The main emphasis is on the actual inclusion of students in the performance of civil and administrative functions. Successful participation in self-government is reflected in the characteristics, which are the second most important document after the certificate for admission to a good college or university [7, p. 258].

In addition to the above, within the civic education framework for high school students, there are relatively affordable internship programs in government at the city and even state level. During these internships, students work in the offices of mayors, city managers, governors, senators, and members of the House of Representatives: those whose characteristics contain indications of leadership qualities and team management skills can go on a summer vacation to the "camps of future leaders", where they not only have the opportunity to have a good holiday but also comprehend various aspects of management and leadership. In the 1980s, up to onethird of American high school students participated in school self-government. In the USA and the UK, student councils are a system of prefects or "class presidents", i.e. "captains", elected by universal secret ballot. Prefects must monitor discipline and have the right, if necessary, to impose various penalties on classmates. Separate school self-government structures resemble a miniature version of American political institutions. In many schools in the United States, there are elections, school president, vice president, treasurer, chairpersons of committees on some issues of the functioning of the educational institution, etc.

During the 1960 s - 1970s, the volume of teaching socio-political subjects in schools throughout the "Western world" increased by almost a third. In colleges, these are usually elective courses that complement the primary subject. For example, the discipline "Social Learning" includes such courses as: "World History", "History of the USA", "World Geography", "Geography of the USA", "History and geography of the native state", "State Government", as well as "The US State system". All these elective courses involve the assimilation by students of more in-depth and systematised information on various branches of social and humanitarian knowledge.

"An American schoolboy may not find the Urals on the map and not answer the question when Luther lived - before or after the Thirty Years' War. But he understands how his native state is organised, what functions and duties Congress and the president have, what taxes are collected and spent on, what insurance is needed, and how to issue it properly. The student sees and understands the close connection between politics and economics. He knows, at least, the general principles of US law and can reproduce from memory the first lines of the preamble of the Declaration of Independence" [8, p. 91].

The United States has indeed developed considerable experience in the development of civic identity and civic education. From this experience, it is clear that this system is focused on teaching young people to perform specific social roles, organically 
instil in them a love for the motherland, and acquaint them with the laws of their country [7, p. 258].

\section{PARADIGM SHIFT, SOCIAL DIVISION AND CHANGES IN AMERICAN EDUCATION}

The end of the 20th and the beginning of the $21 \mathrm{st}$ centuries became the time of a new round of crisis phenomena in American society. It is quite natural that these changes have also affected education. Already at the end of the 1990s, numerous social movements began to assert themselves more and more actively in the United States to one degree or another, aiming at achieving "social justice". Countless human rights non-profit organisations were initially quite useful public tools designed to help the poor, protect national and other minorities, and the rights of women and children. By the mid-2000s, these communities began to turn into a complex conglomerate of various forces with political ambitions and a highly revisionist view of the history and culture of the United States based on the philosophical concepts of the Frankfurt school, neoliberalism, socialism and postmodern philosophy [9, p. 79].

By the time Barack Obama came to the White House in 2009, these organisations, which it had become customary to unite under the common name Social Justice Warriors (SJW), achieved a noticeable influence on politics, finding significant support from the US Democratic Party, which actively used rhetoric about the oppression of various minorities in rivalry with the Republicans. In a spike with the Democrats, SJW and their ideas proved to be in great demand in the cultural field, eventually turning into the mainstream of American culture [9, p. 80-89]. Several movies of the second half of the late 2000s - early 2010s actively worked for a critical rethinking of America's place; the racial issue was again raised extremely sharply, which was not unreasonably considered unresolved within the framework of SJW ideas either after the Civil War or after the abolition of segregation laws in the second half of the 1960s. The most striking examples of such cinematography were the sensational movie "12 years of Slavery" (2013), "The Butler" (2013) and some others. Each of these films painted a picture of unresolved racial problems in the United States, the "eternal" racism of the white population towards black fellow citizens and, in general, the impasse and hypocrisy of the development of the United States for almost the entire history. A separate bright moment in these films (especially "The Butler") was drawn by the victory of Barack Obama in the presidential election, which SJW perceived as the beginning of radical transformations in the public and cultural life of the United States [10, p. 470]. Since that time, the so-called "Critical Race Theory" began to be actively introduced into education, which examines the entire American history from the point of view of racial politics and oppression of the black population. This theory actively asserts that throughout the history of the United States, all sorts of changes in legislation, domestic and sometimes foreign policy was primarily associated with the desire to preserve the belittled position of African Americans in the United States. By the end of the Obama presidency, this theory began to emerge from the walls of US universities and adapt to school programs of civic education [11].

Another notable initiative related to the revision of American history and the foundations of American civic identity is the "Project 1619", initially an extensive material by the most prominent columnists of the most significant American left-liberal publications, such as The New York Times and The New York Times Magazine, as well as some others. Within the framework of this historical and journalistic project, journalists concluded that the history of the United States itself is misinterpreted due to incorrect "starting coordinates", according to which the first permanent settlements of British colonists and, in general, the purposeful development of North America began in the 1620s with the foundation of the first pilgrim settlements. According to the authors of the project, all this is fundamentally wrong; they consider it necessary to count the actual development of America from the first batches of African slaves imported by the British in 1619 as labour for future permanent settlers [12]. Appeared in 2019, this project was quickly picked up by the most liberal part of the American professorship and promptly adapted for teaching in schools together with the "critical race theory". However, its introduction into school education was associated with many difficulties. A significant report created by the Ministry of Education of the State of Illinois noted considerable opposition to the project from the parent community, as well as the blurring of the evidence base, which led to conflict situations and disputes in classrooms between teachers and students, as well as a generally sceptical and hostile attitude of the teaching community to the new 
initiative [13]. The project was actively supported by the Democratic Party of the USA and many of the country's largest media, both TV channels and social networks and Internet media. The very appearance of this project and active attempts to introduce it into the US educational system have become an additional vector of the split of American society and a new topic for controversy among politicians and representatives of the educational sphere. One of the latest initiatives of President Donald Trump was the creation of the "1776 Commission" (the year of signing the Declaration of Independence), the purpose of which was to review existing civic education programs in the States to promote patriotic education in schools and universities [14, p. 180]. The report prepared by the commission evidently consolidated the traditional view of such problems as the history of slavery and the struggle of the African-American population for their rights. Also, the commission concluded that modern civic education in the USA is in a severe crisis because: "there is a polarisation of opinions even within one school, more liberal teachers often spend hours on history and other social disciplines openly imposing revisionist concepts on schoolchildren in the field of history and civic education" [15, pp. 1-2, 10$15]$.

\section{CONCLUSIONS}

Thus, to date, American civic education in the field of civic identity formation is going through the stages of a severe systemic crisis expressed in an acute clash of two extremely opposing views on their history and society. At the same time, the methods developed over previous historical periods allow American education to continue to maintain a prominent position in the field of education of patriotism and citizenship.

\section{AUTHOR'S CONTRIBUTION}

Ya.A. Levin - analysed foreign sources and literature, general control throughout the study. A.O. Buranok - analysis of the national historiography of the topic, formulation of individual conclusions.

\section{ACKNOWLEDGMENTS}

The work was prepared within the framework of project No. 073-00065-21-01 dated 07/14/2021 of the state assignment of the Ministry of Education of the Russian Federation.

\section{REFERENCES}

[1] A. Brown, The Genesis of the United States, Houghton Mifflin, 2009, 756 p.

[2] V.V. Sogrin, Central Problems of US History [Central'nye problemy istorii SSHA], The Whole World Publishing House [Izdatel'stvo «Ves' Mir»], 2013, 352 p.

[3] U.S. Department of Education, National Center for Education Statistics, 120 Years of American Education: A Statistical Portrait, Washington, D.C.: U.S. GPO, 1993.

[4] J.W. Fraser, The School in the United States: A Documentary History, McGraw-Hill, 2001, 366 p.

[5] I. Ahmad, Citizenship Education in the United States: A Historical Perspective, Taylor \& Francis Group, 2019, 128 p.

[6] Z.A. Malkova, Actual problems of education in the USA [Aktual'nye problemy vospitaniya v SSHA], Pedagogy [Pedagogika] 7 (2000) 75-95

[7] T.A. Aseeva, Foreign experience in the formation of citizenship in the process of political socialisation [Zarubezhnyj opyt formirovaniya grazhdanstvennosti $\mathrm{v}$ processe politicheskoj socializacii], Proceedings of the Altai State University [Izvestiya Altajskogo gosudarstvennogo universiteta] 4-1(84) (2014) 255-259.

[8] G.G. Vorobyov, Is it easy to study at an American school? [Legko li uchit'sya v amerikanskoj shkole?], Prosveshchenie, 1993, $192 \mathrm{p}$.

[9] A. Adams, Iconoclasm, Identity Politics and the Erasure of History, Societas, 2020, 167 p.

[10] J. Belton, American Cinema/American Culture, McGraw Hill, 2021, 480 p.

[11] Critical Race Theory in Education, D. Gilborn (Ed.), Taylor \& Francis Group, 2020, 226 p.

[12] The New York Magazine, The 1619 Project. Ed. by J. Silverstein (Ed.), NYT Press. 2019.

[13] U.S. Department of Education, Illinois State Board of Education. The 1619 Project and Chicago Public Schools, Chicago (IL): SPO, 2020.

[14] Educational Foundations, An Anthology of Critical Readings, A.S. Canestrari (Ed.), SAGE Publications, 2020, 264 p.

[15] U.S. Department of Education and The President's Advisory 1776 Commission, The 1776 Final Report, Washington, D.C.: U.S. GPO, 2021. 